\title{
Corporate Social Responsibility in a Competitive Business Environment
}

\section{Carol Newman, John Rand, Finn Tarp \& Neda Trifkovic}

To cite this article: Carol Newman, John Rand, Finn Tarp \& Neda Trifkovic (2020): Corporate Social Responsibility in a Competitive Business Environment, The Journal of Development Studies, DOI: $10.1080 / 00220388.2019 .1694144$

To link to this article: https://doi.org/10.1080/00220388.2019.1694144

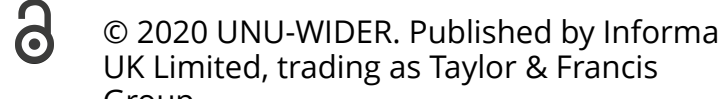
Group

+ View supplementary material $\widetilde{ }$

曲 Published online: 13 Jan 2020.

Submit your article to this journal

LII Article views: 289

Q View related articles 5

View Crossmark data \lceil 


\title{
Corporate Social Responsibility in a Competitive Business Environment
}

\author{
CAROL NEWMAN*, JOHN RAND**, FINN TARP** \& NEDA TRIFKOVIC** \\ *Department of Economics, Trinity College Dublin, Dublin, Ireland, **Department of Economics, University of Copenhagen, \\ Copenhagen, Denmark
}

(Original version submitted May 2018; final version accepted November 2019)

\begin{abstract}
Using a representative sample of more than 5,000 Vietnamese enterprises, we explore the firm-level productivity effects of corporate social responsibility (CSR). The data enables us to create 12 quantitative CSR measures, which can be grouped into two broader categories related to management and community-based CSR initiatives. We find a positive relationship between adoption of CSR initiatives and firm efficiency, and reveal that the impact is stronger for firms in non-competitive industries. Moreover, we show that local community focused CSR initiatives drive the aggregate effect. This suggests that socially responsible actions by firms are likely to pay-off when stakeholder engagement has a localised focus. We provide evidence of reciprocity by showing that employees accept a lower share of additionally generated value-added (controlling for productivity differences) in exchange for working in a company that signals 'good' corporate values.
\end{abstract}

\section{Introduction}

While the concept of Corporate Social Responsibility (CSR) has been widely discussed (Kitzmueller \& Shimshack, 2012), there is neither general agreement about its definition nor a common way of quantifying CSR at the individual firm level. Moreover, there are varying interpretations in the literature about whether CSR improves firm performance and/or whether improvements in CSR levels are necessary for firm survival at given performance rates (Crifo \& Forget, 2015). One key way of looking at improvements in CSR, which we pursue here, is that they form part of developing a modern enterprise in a competitive environment. If a firm wants to survive, it must 'follow the current' and improve its level of CSR. Not doing so reflects 'managerial slack', and will subsequently result in firm closure.

From a policy perspective understanding the relationship between firm performance and corporate governance in competitive and non-competitive industries, respectively, is important for designing appropriate industrial policy (Giroud \& Mueller, 2010). If improving industry competition (such as deregulation and antitrust laws) automatically mitigates managerial agency problems then policies to improve corporate governance will be more efficient if focus is directed towards non-competitive industries.

Correspondence Address: John Rand, Department of Economics, University of Copenhagen, Øster Farimagsgade 5, Copenhagen K 1353, Denmark. Email: john.rand@econ.ku.dk

Supplementary Materials are available for this article which can be accessed via the online version of this journal available at https://doi.org/10.1080/00220388.2019.1694144

(C) 2020 UNU-WIDER. Published by Informa UK Limited, trading as Taylor \& Francis Group

This is an Open Access article distributed under the terms of the Creative Commons Attribution-NonCommercial-NoDerivatives License (http://creativecommons.org/licenses/by-nc-nd/4.0/), which permits non-commercial re-use, distribution, and reproduction in any medium, provided the original work is properly cited, and is not altered, transformed, or built upon in any way. 
A complex set of social preferences and market imperfections motivate CSR. At the same time, the evidence of the effects of CSR on firm performance and labour compensation is mixed at best. First, CSR is found to increase firm profits and improve general firm performance if it enables (i) lower production (environmental) costs; (ii) product differentiation through price discrimination mechanisms working in favour of the socially responsible firm; or (iii) innovation both in terms of managerial processes as well as technological upgrading (Crifo \& Forget, 2015). However, managerial slack and decreasing profits are also observed in cases where the delegated responsibilities to firm executives lead to outcomes favouring the interests of stakeholders other than shareholders. Second, competition may have differential effects on CSR adoption and firm performance. If enterprises in competitive settings compete for socially responsible consumers, CSR activities may be boosted by market competition, improving in turn overall industry efficiency. On the other hand, realising that CSR provides a competitive edge, firms can use CSR strategically to raise entry barriers, increasing relative levels of industry concentration through, for example, influence on the regulatory system. This may in turn reduce firm-level dynamics and industry-level productivity. Third, employees can also be affected by CSR. Socially and environmentally responsible firms have an advantage in hiring motivated and skilled employees, which yields higher labour productivity (Delmas \& Pekovic, 2013; Nyborg, 2014). While employees in CSR firms may show higher levels of dedication and success at work, they are also more likely to accept lower than market wages compared to other workers (Crifo \& Forget, 2015).

We use four consecutive rounds of Vietnamese enterprise surveys from 2011 to 2014 (with rich information on CSR behaviour at the firm level) covering 5,185 enterprises (20,740 firm observations) to answer three empirical questions: (i) Does CSR lead to improvements in firm performance? (ii) Does CSR have a differential impact on firm-level (labour) productivity depending on the level of industry competition? (iii) Do firms use CSR strategically to offer lower labour compensation shares?

Vietnam is an illuminating case for exploring the potential impacts of CSR on firm-level performance. Initially, social initiatives implemented at the firm level were partly introduced through trade-related codes of conduct and partly through increasing engagement by multinationals in Vietnam (Nguyen, 2007). In 2007, the Global Compact Network Vietnam was launched to motivate Vietnamese companies to implement and establish corporate policies relating to labour and environmental standards, human rights, and anti-corruption (UN, 2014). This came at the same time Vietnam entered the World Trade Organisation (WTO), which increased exposure to and knowledge about international standards. This in turn increased the need for well-designed CSR strategies at the firm level to ensure sustainable integration of Vietnamese enterprises into global supply chains. Another reason for studying CSR in the context of Vietnam is its history of communist rule. To our knowledge, it remains unclear how the influence of communism affects CSR activity during a transition towards a more market-oriented economy. On the one hand, Ockenfels and Weimann (1999) find evidence that communism undermines people's propensity for voluntary pro-social activities. On the other hand, communist authorities may be better placed to put pressure on private firms to pursue CSR activities, and may even through State Owned Enterprises (SOEs) and other corporate structures with state ownership positively affect the provision of public goods (Trifkovic, Markussen, Newman, \& Rand, 2018).

Observing the full range of firm activities is difficult and so is measuring CSR, which tends to address a range of stakeholder concerns and to be manifested in a variety of activities, from certification of environmental standards to donations to the non-profit sector. This leads to analytical problems in studies that link CSR behaviour and firm performance. For example, the effect of CSR on firm performance may be underestimated if the CSR metrics are noisy indicators of true CSR activities (Chatterji, Levine, \& Toffel, 2009). Even though crucial for establishing the mechanisms through which CSR affects outcomes, simultaneous treatment of different forms of CSR within one study is, to the best of our knowledge, generally missing in the literature.

In this paper we focus on two dimensions of CSR including the extent to which the firm (i) has a well-developed CSR strategy at the management level that goes beyond compliance with existing regulations (management-related CSR - four indicators); and (ii) engages in beyond-compliance 
activities not directly linked to firm operations (community/society-related CSR - eight indicators). ${ }^{1}$ Based on these two indicators, we generate a CSR index measuring the degree of beyond-compliance CSR-related activities undertaken by the individual firm. We use these distinct categories of CSR activities to uncover the likely mechanisms underlying the CSR-productivity relationship.

Our results show a positive relationship between CSR adoption and firm efficiency. Controlling for unobserved heterogeneity, adding one additional activity to a firm's strategic CSR portfolio gives on average a well-determined 0.3 per cent increase in labour productivity. In addition, the positive relationship between CSR adoption and firm efficiency is stronger for firms in non-competitive industries. Disaggregating this effect by type of CSR engagement reveals that the aggregate effect is largely driven by community-level CSR initiatives. The impact of beyond-compliance CSR, and of community-based CSR activities in particular, on firm performance also emerges applying different generalised method of moments (GMM) estimators. On average, each additional community-related CSR initiative results in a 0.5 to 0.6 per cent increase in labour productivity, and again there is an indication of the effect being stronger in non-competitive industries. Moreover, the stronger community-related CSR effect is found among firms that are more deeply rooted in the local community (sourcing most inputs locally and having most of their customers within the province/district). This confirms that socially responsible actions by Vietnamese private domestic firms are to some extent likely to be reciprocated. Finally, results reveal that employees are willing to accept a lower share of the additionally generated value-added (controlling for productivity) in exchange for working in a company signalling 'good' corporate values especially benefitting the local community.

Our paper adds to the literature on the impact of corporate social behaviour on firm-level performance with insights on how the effect of CSR differs by the level of industry concentration and by the type of CSR engaged in. Focusing on different manifestations of CSR, we also contribute to understanding how these potential added benefits from CSR are distributed among stakeholders and workers. Most CSR studies focus on Europe and USA and a recent review of studies on CSR emphasises the need for more empirical tests of the mechanisms driving CSR and its impact on firm performance in emerging countries (Crifo \& Forget, 2015). To our knowledge, the present study is one of the first attempts to systematically map such cross-firm CSR differences for a fast-growing transition economy.

The paper is structured as follows. Section 2 presents key concepts that underpin our analysis, while Section 3 defines our quantitative measures of CSR and competitiveness. Section 4 presents the data and the empirical framework, and Section 5 the results. Section 6 concludes.

\section{Concepts}

Although several papers have tried to pin down indicators of CSR, no common measurement or definition exists (Crifo \& Forget, 2015). In some definitions, CSR refers to firm activities that go beyond the law in incorporating social, environmental, ethical, and consumer concerns into their business operations to create shareholder and stakeholder value (Bénabou \& Tirole, 2010; Crifo \& Forget, 2015; McWilliams \& Siegel, 2001). Common societal expectations are that firms achieve their economic objectives within the legal framework (Carroll, 1979). While this could be taken as given in advanced economies, it may not hold in developing countries, where the rule of law may not be enforced to the extent expected (see, for example, Barrett, Browne, Harris, \& Cadoret, 2002). In other definitions, CSR is identified as a mix of economic, legal, and ethical responsibilities of businesses (Schwartz \& Carroll, 2003). The UN Global Compact for example considers compliance with laws and regulations including labour conditions and anti-corrupt behaviour an integral part of CSR (UN, 2013). In this paper, we follow the literature referring to CSR as what firms do to further the social good beyond the law, but at the same time we acknowledge the context within which the analysis is done, and take into account in our estimation approach whether firms in fact do live up to the legal requirements expected of them. 
The literature highlights several reasons for a positive association between CSR and firm performance. First, a positive effect may come through improvements in the company's image and reputation, which in turn has been shown to influence firm competitiveness and performance, at least in the long run. Second, an improved CSR strategy may increase employee motivation, retention, and recruitment. This effect may come through the above-mentioned reputation improvement, or directly through an employees' motivation effect due to (perceived) improvements in the working environment. Third, CSR strategies may lead to efficiency gains as firms become more open to alternative production strategies and to investors with a higher sensitivity to sustainability issues. Fourth, improvements in CSR may lead to revenue increases; either indirectly through improved brand image or directly by CSR-driven product or market development (niche markets). Finally, CSR is a means to reduce or manage CSR-related risks such as the avoidance of negative press coverage. CSR, however, does not necessarily result in improved firm performance as documented in a recent meta-study by Margolis, Elfenbein, and Walsh (2009). This finding is related to the fact that some shareholders care about social or environmental performance to the degree that they willingly trade profits and firm-level performance for social goods (Kitzmueller $\&$ Shimshack, 2012). Although shareholder preferences for CSR may influence firm-level efficiency negatively, the five above described mechanisms lead to our first hypothesis (H1).

\section{H1: There is a positive relationship between CSR provision and firm-level productivity.}

Campbell (2007) argues that firm-level CSR activities are likely to be lower in competitive settings, and that the relationship between industry competitiveness and firm-level socially responsible activities is nonlinear. Bagnoli and Watts (2003) agree that the provision of CSR and industrylevel competition will be inversely related, so a trade-off exists between the optimal level of CSR activities and firm-level efficiency. This is in accordance with Porter and Kramer (2002), who argue that concentrated sectors have lower rates of CSR adoption because firms lack incentives to engage in a socially responsible manner due to lower potential impacts of increasing competitive advantages. In addition, when competition is perfect, firms search for immediate cost-reducing strategies, which likely involve reducing beyond-compliance related socially responsible initiatives, to ensure firm survival (Shleifer, 2004). According to Porter and van der Linde (1995), certain environmental standards and regulations can push forward innovative ideas and subsequently reduce production costs, resulting in dynamic competitive advantages. The speed at which this process evolves will depend on industry-level competition, thereby leading to a hypothesis of differential impacts of socially responsible behaviour on firm-level productivity along the competition dimension. Bénabou and Tirole (2010) show that assuming a limit on firm managers' temporal horizon of corporate governance, a negative relationship between firm-level provision of CSR activities and industry-level competitiveness can be observed. Stakeholder monitoring of firm executives is needed to correct for the management's 'short sightedness', but such monitoring tools will be less effective in competitive settings, that is, leading to a differential efficiency impact of CSR along the industry competitiveness dimension. This result is also shown to apply in settings where shareholders are willing to sacrifice firm profits (philanthropy) to promote CSR behaviour. Applying a transaction cost argument, philanthropy through corporations (delegated monitoring) is optimal if transaction costs are lower for corporations than for investors. In such cases, greater prevalence of CSR practices is more likely to be found among larger, more profitable firms, leading in turn to predict an inverse relationship between CSR provision and industry competition. ${ }^{2}$ The theoretical prediction that the impact of CSR on firm-level productivity varies with the degree of competition leads to our next hypothesis.

H2: There is positive relationship between CSR provision and firm-level productivity, but the effect diminishes with industry-level competition.

Finally, the idea that employees value the social responsibility of their employers has been proposed both in theory and tested empirically (Besley \& Ghatak, 2005; Brekke \& Nyborg, 2008, 
2010; Heal, 2005; Nyborg \& Zhang, 2013). In a model allowing for moral hazard and heterogeneous principals and agents, it can be shown that pecuniary extrinsic incentives (bonus payments) and the workers intrinsic motivation can act as substitutes (Besley \& Ghatak, 2005). Crifo and Forget (2015) also show that motivated employees may accept a wage below the equilibrium market value because they enjoy non-monetary compensation through working in a firm aligned with their personal values. If CSR helps incentivise and motivate workers and makes it easier to attract highly qualified employees, we expect to find a positive association between CSR and firm-level productivity, through an employee 'inspiration' effect (Akerlof \& Kranton, 2005). All else given, a worker with a stronger inclination for social responsibility would value working in a firm with higher CSR provision and this preference implies that there exists a strictly positive wage differential such that even if the socially responsible firm offers a lower wage by this amount, the employee would still prefer working in a firm with higher levels of CSR provision (Nyborg \& Zhang, 2013). For a given productivity level, we therefore expect that the net effect of CSR on the labour compensation package negotiated between workers and employers of the additional value added gained due to the positive productivity effect of CSR will be negative, which leads to our third and final hypothesis.

H3: There is a negative relationship between CSR provision and labour compensation ratios (controlling for productivity differences).

\section{Data and CSR and competitiveness definitions}

Our data originate from two sources. First, we use the 2011-2014 Vietnam Enterprise Surveys (VES) collected by the General Statistics Office (GSO), which include the population of all registered manufacturing enterprises with 30 employees or more and a representative sample of the remaining smaller formally registered firms. However, among the surveyed enterprises some were found to report inconsistent financial records and were therefore excluded from the analysis. This leaves us with a sample of approximately 40,000 manufacturing firms with detailed data on general firm characteristics and performance. The GSO data are thoroughly described in Newman, Rand, and Tarp (2013, 2015). Second, from the above nationwide enterprise survey, a sample of approximately 8,000 manufacturing firms was selected based on a stratified (by region and sector, 2-digit ISIC) random sampling approach to respond to a specific technology, CSR, and competitiveness survey module referred to as the TCS survey (Central Institute for Economic Management [CIEM], GSO, \& University of Copenhagen, 2015). Combining the two surveys leaves us with a balanced panel of 5,185 firm observations over time and a total of 20,740 observations. Summary statistics of the variables used in the analysis are documented in Table 1 (split by high (column 2) and low (column 3 ) levels of competition and by whether the firms comply (column 4) or do not comply (column 5) with current labour laws - see definition below). ${ }^{3}$

The average revenue per employee is 121 million VND with substantial differences between sectors by competition. Competitive sectors show better performance with 130 million VND per employee on average, compared to 96 million VND in less competitive sectors. The average firm size is 78 employees, reaching 90 in competitive, and 66 in less competitive sectors, respectively. Competitive and non-competitive sectors do not show a huge gap in the value of capital, which averages 103 million VND in sectors with weak, and 111 million VND in sectors with high, competition. The value of inputs per employee is higher in competitive sectors. Returns to assets are, however, 40 per cent higher in weakly competitive sectors. Similar shares of value added are distributed to labour in both types of sectors. Weakly competitive sectors show a higher prevalence of state-owned firms and a lower prevalence of foreign firms. Firms in these sectors tend to have more research and development $(\mathrm{R} \& \mathrm{D})$ activities and more frequently produce goods for final consumption. They are also less likely to export than firms in more competitive sectors. 
Table 1. CSR summary statistics, by HHI quintiles

\begin{tabular}{|c|c|c|c|c|c|c|c|c|c|c|}
\hline & \multicolumn{2}{|c|}{ (1) } & \multicolumn{2}{|c|}{ (2) } & \multicolumn{2}{|c|}{ (3) } & \multicolumn{2}{|c|}{ (4) } & \multicolumn{2}{|c|}{ (5) } \\
\hline & \multicolumn{2}{|c|}{ All } & \multicolumn{2}{|c|}{$\mathrm{HHI}<20 \%$} & \multicolumn{2}{|c|}{$\mathrm{HHI}>80 \%$} & \multicolumn{2}{|c|}{$\begin{array}{l}\text { Legal } \\
\text { compliers }\end{array}$} & \multicolumn{2}{|c|}{$\begin{array}{l}\text { Non- } \\
\text { compliers }\end{array}$} \\
\hline & Mean & SD & Mean & SD & Mean & SD & Mean & SD & Mean & SD \\
\hline \multicolumn{11}{|l|}{ CSR indicators } \\
\hline CSR index $-(0-12)$ & 2.111 & $(1.759)$ & 1.787 & $(1.491)$ & 2.476 & (1.947) & 2.447 & $(1.849)$ & 1.750 & $(1.579)$ \\
\hline $\begin{array}{l}\text { CSR level relative to sector } \\
\text { average (by year) }\end{array}$ & 1.000 & $(0.823)$ & 0.900 & $(0.753)$ & 1.136 & $(0.888)$ & 1.154 & $(0.857)$ & 0.834 & $(0.751)$ \\
\hline $\begin{array}{l}\text { CSR index A - Management } \\
(0-4), \text { mean }\end{array}$ & 1.314 & $(0.889)$ & 1.230 & $(0.849)$ & 1.363 & $(0.896)$ & 1.557 & $(0.894)$ & 1.051 & $(0.804)$ \\
\hline $\begin{array}{l}\text { CSR index B - Community } \\
(0-8), \text { mean }\end{array}$ & 0.798 & $(1.330)$ & 0.557 & $(1.047)$ & 1.112 & $(1.501)$ & 0.890 & $(1.429)$ & 0.699 & $(1.206)$ \\
\hline \multicolumn{11}{|l|}{ Industry competition } \\
\hline $\begin{array}{l}\text { Hirschman/Herfindahl Index } \\
\text { by industry and province } \\
\text { (HHI1) }\end{array}$ & 0.149 & $(0.175)$ & 0.021 & $(0.008)$ & 0.429 & $(0.206)$ & 0.146 & $(0.178)$ & 0.153 & $(0.172)$ \\
\hline $\begin{array}{l}\text { Hirschman/Herfindahl Index } \\
\text { by industry (HHI2) only }\end{array}$ & 0.041 & $(0.059)$ & 0.023 & $(0.036)$ & 0.060 & $(0.078)$ & 0.042 & $(0.063)$ & 0.040 & $(0.055)$ \\
\hline \multicolumn{11}{|l|}{ Production function } \\
\hline $\begin{array}{l}\text { Revenue per employee, real } \\
\quad(\log )\end{array}$ & 4.795 & $(1.129)$ & 4.867 & $(0.984)$ & 4.564 & $(1.116)$ & 4.952 & $(1.096)$ & 4.626 & $(1.139)$ \\
\hline $\begin{array}{l}\text { Labour (full-time permanent } \\
\text { employees, log) }\end{array}$ & 4.352 & $(1.407)$ & 4.505 & $(1.361)$ & 4.188 & $(1.426)$ & 5.041 & $(1.315)$ & 3.610 & $(1.089)$ \\
\hline $\begin{array}{l}\text { Capital per employee, real } \\
(\log )\end{array}$ & 4.723 & $(1.097)$ & 4.714 & $(1.036)$ & 4.637 & $(1.083)$ & 4.805 & $(1.119)$ & 4.634 & $(1.066)$ \\
\hline $\begin{array}{l}\text { Inputs per employee, real (log) } \\
\text { Additional financial variables }\end{array}$ & 4.555 & $(1.315)$ & 4.627 & $(1.169)$ & 4.306 & $(1.315)$ & 4.687 & $(1.310)$ & 4.413 & $(1.306)$ \\
\hline $\begin{array}{l}\text { Return on Assets - RoA } \\
\text { (profits as a share of total } \\
\text { assets) }\end{array}$ & 0.025 & $(0.401)$ & 0.017 & $(0.161)$ & 0.024 & $(0.146)$ & 0.032 & $(0.175)$ & 0.018 & $(0.549)$ \\
\hline $\begin{array}{l}\text { Wage share } \\
\text { (labour cost as a share of } \\
\text { total value added) }\end{array}$ & 0.870 & $(0.266)$ & 0.890 & $(0.251)$ & 0.877 & $(0.252)$ & 0.835 & $(0.290)$ & 0.908 & $(0.231)$ \\
\hline \multicolumn{11}{|l|}{ Additional controls } \\
\hline State involvement (Yes & 0.043 & $(0.204)$ & 0.034 & $(0.182)$ & 0.061 & $(0.240)$ & 0.076 & $(0.265)$ & 0.008 & $(0.089)$ \\
\hline Foreign involvement $($ Yes $=1)$ & 0.247 & $(0.432)$ & 0.288 & $(0.453)$ & 0.170 & $(0.376)$ & 0.379 & $(0.485)$ & 0.106 & $(0.308)$ \\
\hline $\mathrm{R} \& \mathrm{D}(\mathrm{Yes}=1)$ & 0.092 & $(0.289)$ & 0.070 & $(0.255)$ & 0.123 & $(0.329)$ & 0.131 & $(0.338)$ & 0.050 & $(0.219)$ \\
\hline Final use production $($ Yes $=1)$ & 0.609 & $(0.488)$ & 0.562 & $(0.496)$ & 0.640 & $(0.480)$ & 0.614 & $(0.487)$ & 0.604 & $(0.489)$ \\
\hline Exporter $($ Yes $=1)$ & 0.386 & $(0.487)$ & 0.491 & $(0.500)$ & 0.264 & $(0.441)$ & 0.567 & $(0.495)$ & 0.191 & $(0.393)$ \\
\hline Compliance $($ Comply $=1)$ & 0.519 & $(0.500)$ & 0.616 & $(0.486)$ & 0.491 & $(0.500)$ & 1.000 & $(0.000)$ & 0.000 & $(0.000)$ \\
\hline Total observations & &, 740 & & 007 & & 170 & &, 756 & & 984 \\
\hline
\end{tabular}

Source: Authors' calculations based on CIEM et al. (2015).

Notes: HHI is defined at the 2-digit ISIC level and at the province level. Using the nationwide HHI index does not qualitatively change the overall picture.

\subsection{Measuring industry competitiveness}

Our main measure of competition is the Herfindahl-Hirschman index (HHI), which is well grounded in industrial organisation theory. Given provincial autonomy in Vietnam and lack of cross-province marketing and sourcing, we choose to define the HHI as the sum of squared market shares within each province:

$$
H H I_{p s t}=\sum_{i=1}^{N} m_{i p s t}^{2}
$$


where $m_{i p s t}$ is the market share of firm $i$ in province $p$, in industry $s$, in year $t$. This means that a higher HHI implies weaker competition, thus higher concentration. The market shares are computed from the more than 40,000 yearly manufacturing firm observations from the VES based on the revenue data reported by each individual firm. While our benchmark measure is the sector-province level HHI based on the two-digit ISIC codes (in the following labelled HHI1), we check robustness of the results using a nationwide sector level concentration index (HHI2) as well. ${ }^{4}$ From Table 1 we see that the average HHI1 value is 0.149 , with the value of 0.021 for the most competitive quintile, and 0.429 in the least competitive quintile. HHI2 has a sample average of 0.041 and a difference of 4.3 percentage points between the most and the least competitive quintiles.

\subsection{Measuring CSR}

A single best way of measuring CSR is still to be found (Crifo \& Forget, 2015). Gjølberg (2009) and Turker (2009) provide overviews of several different ways of measuring CSR. A comprehensive set of environmental, social and governance (ESG) performance indicators are also provided by Thomson Reuters (ASSET4). While this database contains 226 key indicators, it only covers 4,600 companies worldwide (Thomson Reuters, 2014), which limits the suitability for single-country studies. In this study, we focus on selected beyond-compliance indicators of CSR, some of which overlap with the Thomson Reuters ESG index (for example, role of management). Our data unfortunately fall short in accounting for environmental performance, such as resource or emission reduction. Our survey instruments do, however, collect detailed data on different CSR aspects, which can be divided into two sub-components (for details see Table 2 and Appendix Table A in the Supplementary Materials by year):

Table 2. Summary statistics, by HHI quintiles

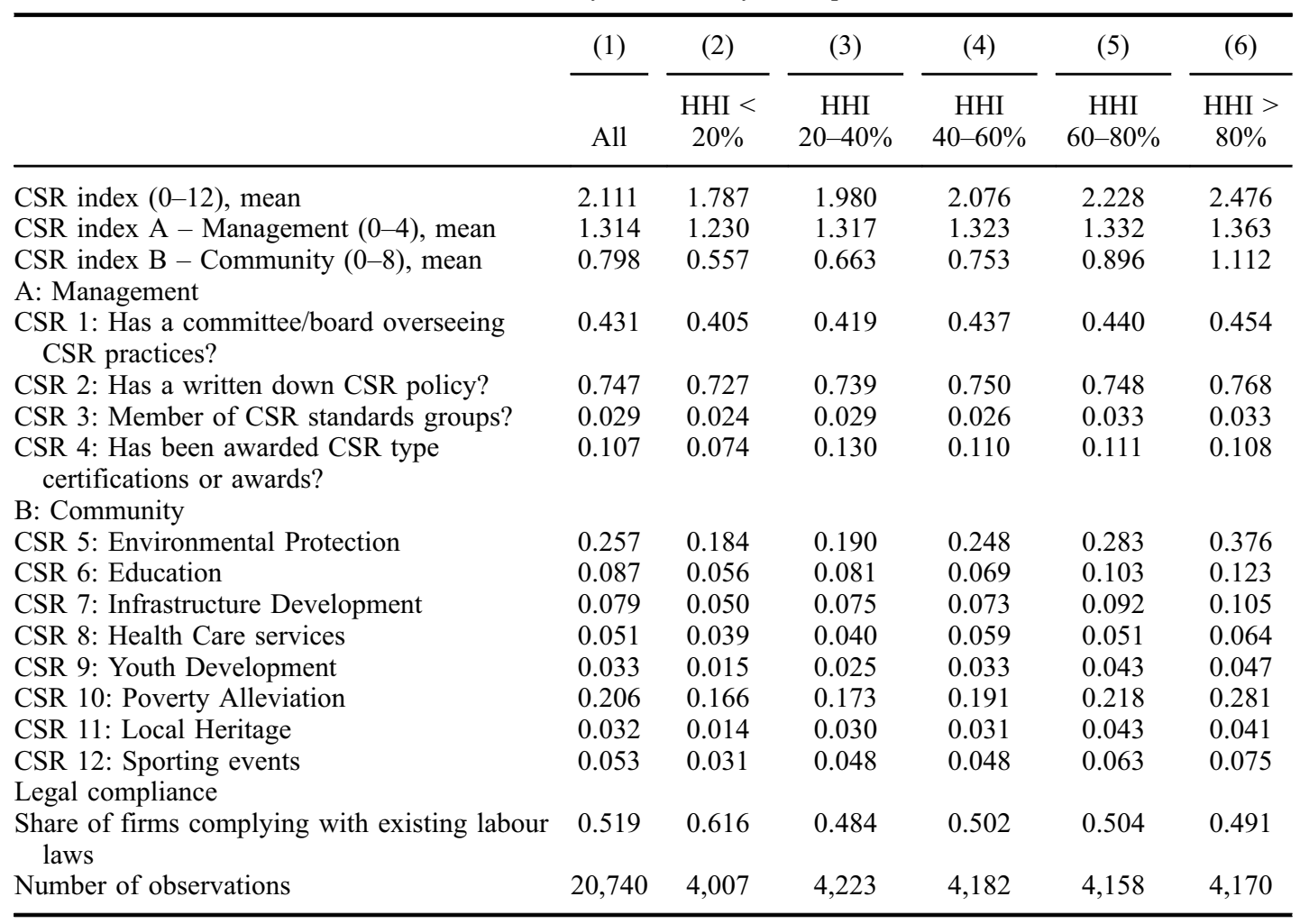

Source: Authors' calculations based on CIEM et al. (2015).

Notes: HHI is defined at the 2-digit ISIC level and at the province level. Using the nationwide HHI index does not qualitatively change the overall picture. 
(a) Management-related responsibilities (4 indicators)

(b) Community-related responsibilities (8 indicators)

Management-related responsibilities capture whether firms embed CSR practices into their business strategy through written down CSR policy, oversight of CSR practices, CSR certifications, such as ISO 9001, ISO 14001 or Social Accountability (SA) 8000, and agreements on the promotion of CSR standards. This component of CSR is not to be neglected as interests of managers and directors may motivate CSR (Jensen, 2002).

Indicators of community-related responsibilities consider the extent to which firms actively engage and support local community activities not directly related to the firm's commercial activities, such as environmental protection and educational programmes, or development of infrastructure and local healthcare services. Community-related CSR measures the way in which firms contribute to the local community in areas that are beyond the immediate business interests of the firm. Local community/ society-related CSR initiatives form part of our CSR index. According to Kitzmueller and Shimshack (2012), a valid CSR definition should not exclude the degree of 'local content' in the firm's corporate behaviour. This also corresponds to Schwartz and Carroll's (2003) ethical domain of corporate activities, which refers to meeting both domestic and global ethical responsibilities towards the general population and relevant stakeholders.

Our measures may not perfectly reflect CSR behaviour and performance, as the nature of the data available to us is such that we can only use self-reported measures of CSR activities (Chatterji et al., 2009). We therefore acknowledge that different CSR activities included in our CSR index may not be equally important for firm operations. Compare, for example, a case of a firm that has a written-down CSR policy that is never implemented in practice, and a case of a firm obtaining a CSR-type certification, which requires adopting specific procedures and verification by an independent third party that specific requirements have been fulfilled. Arguably the latter is a more objective measure of CSR.

We are well aware of the oft-observed weak enforcement of existing regulation in developing country contexts and as recommended in the ISO 26000 and UN Global Compact guidelines (UN, 2004) and in accordance with Schwartz and Carroll (2003) we include a legal compliance control variable, which measures the degree to which firms respond to society's legal expectations. The measure refers to labour standards only as the dataset does not contain information on the compliance with domestic environmental, safety or quality regulation. It is often expected that exporters comply with various destination country regulations. This is usually demonstrated by obtaining certificates of compliance with international standards. These types of certificates are included in management CSR due to the voluntary nature in Vietnam of adopting such standards and obtaining certifications.

For each of the two sub-components of CSR, we score firms by giving them a point for each CSR activity reported. Combining the scores for each sub-component produces our CSR index that shows, on a scale of $0-12$, the overall level of CSR engagement by the firm. It is not obvious from theory how to weigh each component of an aggregated CSR index, so we follow the convention of assigning equal importance to each sub-component of the CSR index established in earlier work (Cheng, Ioannou, \& Serafeim, 2014; Hillman \& Keim, 2001; Waddock \& Graves, 1997; Waldman, Siegel, \& Javidan, 2006).

Column 1 in Table 2 documents the average scores and the percentage of firms engaging in each specific CSR-related category for the full sample. Firms on average score 2 out of 12 on the aggregate CSR index. ${ }^{5}$ A total of 19 per cent do not do any form of management CSR, whereas 61 per cent do not involve themselves in community-related CSR activities. More than 50 per cent of firms comply with all labour-related law requirements.

Looking at averages over time, Appendix Table A in the Supplementary Materials indicates very little within firm changes in CSR behaviour. However, the share of firms changing CSR 'position' over the 2011 to 2014 period within each CSR category is substantial when studying the CSR transition matrices (see CIEM et al. (2015) for details). The number of 'off-diagonal' observations in the transition matrices are especially large within management level CSR whereby 38 per cent of 
firms change their management-related CSR strategy over time. Similarly, 31 per cent of firms change their community-related CSR strategy over time. As an example, firms stating that they are 'carrying out environmental protection activities that go beyond law requirements' in one year and not in the other is quite large (18 per cent). Similarly, 10 per cent of firms stating that they have a 'written down CSR policy' decided to abandon the policy during the four-year period. This suggests that these firms did not have a well-defined CSR strategy in the first place.

Given the focus of this study, we also document in Table 2 each CSR-related indicator by HHI quintile. The unconditional relationship between CSR and competitiveness does not seem to support the view that competition may induce discipline on corporate social behaviour, at least when considering the aggregate CSR index. Firms in more competitive sectors (low HHI) have a lower CSR score as compared to firms in less competitive industries, and the difference seems to be driven especially by differences in community-related CSR.

Appendix Figure 1 in the Supplementary Materials illustrates the interlinkages between the types of CSR firms engage in. We analyse whether a firm doing one type of CSR (say a firm having a committee/board overseeing CSR practices, CSR indicator 1 in Table 2) is more likely to engage in another specific type of CSR practice (say doing a local environmental protection initiative, CSR indicator 5 in Table 2). We conclude that firms which carry out management-related CSR are not likely to also engage in community-based CSR. Consequently, in the following analysis, we distinguish between distinct types of CSR (management or community) when analysing their association with firm-level productivity.

\section{Empirical framework}

The analytical framework for our empirical analysis is a standard production function:

$$
Y_{i, t}=A_{i t} K_{i t}^{\beta_{K}} N_{i t}^{\beta_{N}} M_{i t}^{\beta_{M}} \Rightarrow\left(\frac{Y}{N}\right)_{i, t}=A_{i t}\left(\frac{K}{N}\right)_{i t}^{\beta_{K}} N_{i t}^{\beta_{K}+\beta_{N}+\beta_{M}-1}\left(\frac{M}{N}\right)_{i t}^{\beta_{M}}
$$

Formulated in logarithms and defining $\beta_{n}=\beta_{N}+\beta_{K}+\beta_{M}-1$ we obtain:

$$
y_{i, t}=\beta_{n} n_{i, t}+\beta_{K} k_{i, t}+\beta_{M} m_{i, t}+a_{i, t}+\varepsilon_{i, t}
$$

where $y$ is $\log$ revenue per employee (labour productivity), $n$ is $\log$ firm size (number of equivalent full-time employees), $k$ is log capital per employee (capital intensity), and $m$ is log of intermediate inputs including raw materials per employee (intermediate input intensity). Total factor productivity (TFP) is represented by $a$, and $\varepsilon$ is a serially uncorrelated residual capturing efficiency shocks, assumed to be exogenous and unobservable by the firm. Based on the literature review in Section 2, we hypothesise that TFP is affected by CSR. More specifically we assume:

$$
a_{i, t}=\delta C S R_{i, t}+c_{i, t}+\mu_{i}+\xi_{i, t}
$$

where we allow for heterogeneity in TFP by including controls for location, industry, ownership form (state or foreign), exporter status (indicator variable taking the value one if the firm exports and zero otherwise), research and development (R\&D) (indicator variable taking the value one if R\&D takes place in-house and zero otherwise), production of intermediates or goods for final use (indicator variable taking the value one if final goods are produced and zero otherwise) and compliance with labour laws, summarised by $c$. Unobserved heterogeneity in the form of firm-specific effects is denoted by $\mu_{i}$ and a random error term by $\xi$. Substituting the expression for TFP into (3) forms the basis of our econometric test for efficiency effects due to CSR adoption. Since one of our main aims is to examine whether the adoption of a specific CSR strategy has differential effects on firms in 
competitive and non-competitive industries, we allow for heterogeneous CSR effects along the competitiveness dimension by estimating:

$$
y_{i, t}=\beta x_{i, t}+\delta_{1} C S S R_{i, t}+\delta_{2} H H I_{i, t}+\delta_{3} C S R \cdot H H I_{i, t}+c_{i, t}+\mu_{i}+\eta_{i, t}
$$

where $\beta x_{i, t}=\beta_{n} n_{i, t}+\beta_{K} k_{i, t}+\beta_{M} m_{i, t}$, CSR is an index (0-12) calculated based on the information obtained from answers to the questions described in Table 1 and $H H I$ is the Herfindahl-Hirschman index (HHI) described in Equation (1). Note that for any given HHI value, we can compute the total effect of adopting CSR as $\delta_{1}+\delta_{3} * \mathrm{HHI}$. The coefficient $\delta_{1}$ on the CSR variable measures the (limit) effect as the HHI goes to zero, implying that it measures the CSR effect on firms in highly competitive industries, which according to Hypothesis 1 expect to be positive. The coefficient $\delta_{3}$ measures how the effect varies with the degree of competition, which we according to Hypothesis 2 expect to be positive. The coefficient $\delta_{2}$ thereby captures the direct effect of competition. If the conjecture is that firms in more competitive industries (lower HHI) are more efficient (due to more dynamic creative-destruction processes), then the coefficient $\delta_{2}$ is expected to be negative.

Assuming it takes time for output to reach its new long-run level whenever factors of production are changed and to make serial correlation of the residual less likely, we estimate the following dynamic specification as a robustness check:

$$
y_{i, t}=\lambda y_{i, t-1}+(1-\lambda) \beta x_{i, t}+\delta_{1} C S R_{i, t}+\delta_{2} H H I_{i, t}+\delta_{3} C S R \cdot H H I_{i, t}+c_{i, t}+\mu_{i}+\eta_{i, t}
$$

A simple empirical approach would be to estimate (5) and (6) using OLS or a standard panel GLS estimator. Unfortunately, this approach is likely to yield misleading results if CSR and productivity are correlated for reasons other than causality running from CSR to efficiency. The positive association between CSR and productivity can be due to self-selection of the relatively more efficient firms into more philanthropic endeavours, rather than to efficiency effects of CSR. Moreover, since Equation (6) contains the lagged dependent variable it is important to control for heterogeneity among firms. Otherwise, we would expect the estimates to be upward biased, reflecting 'spurious' state dependence.

While $c$ controls for heterogeneity in certain observed variables, the presence of unobserved heterogeneity in the form of the firm-specific effects $\mu_{i}$ presents us with some econometric challenges. Unobserved firm heterogeneity, such as, for example, product attributes or managerial ability, might affect a firm's CSR decisions. As these are permanent attributes they might lead to persistence in CSR behaviour and hence to an overestimation of the importance of CSR for firm-level efficiency. Under a strict exogeneity assumption, a standard fixed effects model eliminates the unobserved timeinvariant firm-specific effects. However, even with a rich combination of fixed effects and time varying control variables, it is possible that other sources of bias remain. ${ }^{6}$ In addition to a traditional fixed effects approach, we therefore apply a two-step static and dynamic system GMM estimators (Arellano \& Bover, 1995; Blundell \& Bond, 1998). In the results section, we provide more details on the exact lag structure and the validity of the instrument sets. Using this approach, the parameters are identified using the within-firm variation in CSR and labour productivity over time. Given the brief time series of our panel (2011-2014), which may limit the extent of variation used to identify parameters and to avoid the possibility that parameter estimates are influenced by the exit and entry of firms rather than within-firm variations, we focus exclusively on a balanced panel of firms.

\section{Results}

As outlined in the introduction, we wish to establish whether a firm's CSR adoption choice affects firm-level productivity and if there are different effects on firm performance in competitive and noncompetitive industries. Table 3 reports fixed effects results from estimating specification (5) using the HHI1 measure of industry concentration defined above. ${ }^{7}$ 
Looking at the main results in Table 3 in columns 1 and 2, all estimations indicate a positive relationship between CSR adoption and firm efficiency (centred estimates). This means that even when controlling for unobserved heterogeneity, adding one additional beyond-compliance CSR activity to a firm's portfolio gives on average a $0.23-0.27$ per cent increase in labour productivity in highly competitive industries. Moreover, the positive and well-determined interaction term between CSR and HHI indicates that the positive relationship between CSR adoption and firm efficiency is larger for firms in non-competitive industries. Output elasticities of labour, capital, and inputs align throughout with expectations, and the three input variables indicate a production technology close to constant returns to scale. ${ }^{8}$ Perhaps surprisingly, we find no effect of HHI on firmlevel productivity so there is no evidence that firms in non-competitive industries operate less efficiently. ${ }^{9}$

Columns 3 and 4 in Table 3 look at the possible differential effects of different types of CSR (management and community). The positive relationship found between the aggregate CSR index and

Table 3. CSR, productivity and sectoral competitiveness

\begin{tabular}{|c|c|c|c|c|c|c|}
\hline & 1 & 2 & 3 & 4 & 5 & 6 \\
\hline & $\begin{array}{l}\text { ALL } \\
\text { FE }\end{array}$ & $\begin{array}{l}\text { ALL } \\
\text { FE }\end{array}$ & $\begin{array}{l}\text { ALL } \\
\text { FE }\end{array}$ & $\begin{array}{l}\text { ALL } \\
\text { FE }\end{array}$ & $\begin{array}{l}\text { Domestic } \\
\text { FE }\end{array}$ & $\begin{array}{c}\text { State/Foreign } \\
\text { FE }\end{array}$ \\
\hline \multicolumn{7}{|l|}{ Focus variables } \\
\hline CSR index $(0-12)$ & $\begin{array}{c}0.0027 * * * \\
(0.0010)\end{array}$ & $\begin{array}{c}0.0023 * * \\
(0.0011)\end{array}$ & & & $\begin{array}{c}0.0030 * * * \\
(0.0011)\end{array}$ & $\begin{array}{c}0.0020 \\
(0.0023)\end{array}$ \\
\hline CSR index A - Management & & & $\begin{array}{c}0.0011 \\
(0.0019)\end{array}$ & $\begin{array}{c}0.0008 \\
(0.0019)\end{array}$ & & \\
\hline CSR index B - Community & & & $\begin{array}{c}0.0035 * * \\
(0.0014)\end{array}$ & $\begin{array}{l}0.0030 * * \\
(0.0014)\end{array}$ & & \\
\hline Hirschman/Herfindahl Index (HHI) & $\begin{array}{c}0.0021 \\
(0.0221)\end{array}$ & $\begin{array}{l}-0.0212 \\
(0.0244)\end{array}$ & $\begin{array}{c}0.0018 \\
(0.0221)\end{array}$ & $\begin{array}{l}-0.0149 \\
(0.0255)\end{array}$ & $\begin{array}{l}-0.0151 \\
(0.0262)\end{array}$ & $\begin{array}{c}0.0045 \\
(0.0672)\end{array}$ \\
\hline CSR $* H H I$ interaction & & $\begin{array}{l}0.0105 * \\
(0.0057)\end{array}$ & & & $\begin{array}{l}0.0122 * \\
(0.0063)\end{array}$ & $\begin{array}{c}0.0127 \\
(0.0131)\end{array}$ \\
\hline CSR(A)*HHI interaction & & & & $\begin{array}{c}0.0021 \\
(0.0115)\end{array}$ & & \\
\hline CSR(B)*HHI interaction & & & & $\begin{array}{l}0.0144 \% \\
(0.0076)\end{array}$ & & \\
\hline \multicolumn{7}{|l|}{ Efficiency controls } \\
\hline Employment (log) & $\begin{array}{l}-0.0093 \\
(0.0071)\end{array}$ & $\begin{array}{l}-0.0096 \\
(0.0071)\end{array}$ & $\begin{array}{l}-0.0093 \\
(0.0071)\end{array}$ & $\begin{array}{l}-0.0097 \\
(0.0071)\end{array}$ & $\begin{array}{l}-0.0108 \\
(0.0072)\end{array}$ & $\begin{array}{l}-0.0138 \\
(0.0224)\end{array}$ \\
\hline Assets per employee $(\log )$ & $\begin{array}{c}0.0614 * * * \\
(0.0073)\end{array}$ & $\begin{array}{c}0.0614 * * * \\
(0.0073)\end{array}$ & $\begin{array}{c}0.0614 * * * \\
(0.0073)\end{array}$ & $\begin{array}{c}0.0614 * * * \\
(0.0073)\end{array}$ & $\begin{array}{c}0.0460 * * * \\
(0.0072)\end{array}$ & $\begin{array}{c}0.1324 * * * \\
(0.0203)\end{array}$ \\
\hline Inputs per employee $(\log )$ & $\begin{array}{c}0.7786 * * * \\
(0.0093)\end{array}$ & $\begin{array}{c}0.7784 * * * \\
(0.0093)\end{array}$ & $\begin{array}{c}0.7786 * * * \\
(0.0093)\end{array}$ & $\begin{array}{c}0.7784 * * * \\
(0.0093)\end{array}$ & $\begin{array}{c}0.8135 * * * \\
(0.0080)\end{array}$ & $\begin{array}{c}0.6030 * * * \\
(0.0323)\end{array}$ \\
\hline Compliance control & & $\begin{array}{l}0.0080 * \\
(0.0046)\end{array}$ & & $\begin{array}{l}\text { 0.0081* } \\
(0.0046)\end{array}$ & $\begin{array}{c}0.0062 \\
(0.0050)\end{array}$ & $\begin{array}{c}0.0092 \\
(0.0095)\end{array}$ \\
\hline Additional controls & No & Yes & No & Yes & Yes & Yes \\
\hline Obs. & 20,740 & 20,740 & 20,740 & 20,740 & 14,764 & 5,584 \\
\hline Firms & 5,185 & 5,185 & 5,185 & 5,185 & 3,691 & 1,396 \\
\hline Joint significance ALL (p-value) & & 0.009 & & & 0.003 & 0.412 \\
\hline Joint significance A (p-value) & & & & 0.913 & & \\
\hline Joint significance B (p-value) & & & & 0.007 & & \\
\hline R-squared (within) & 0.88 & 0.88 & 0.88 & 0.88 & 0.92 & 0.68 \\
\hline
\end{tabular}

Source: Authors' calculations based on CIEM et al. (2015).

Notes: Dependent variable: Real revenue per employee (log). Firm fixed effects (FE) estimates. Standard errors (reported in parentheses) are heteroscedasticity (cluster) robust. $,^{* *}, * * *$ indicate significance at a 10 per cent, 5 per cent, and 1 per cent level, respectively. Regressions including sector fixed effects (allowing for sector switchers in the FE) do not change the results reported. 
labour productivity is driven mainly by community-related CSR initiatives. This is in line with Liu (2009) who found that community and NGO forces are the most important drivers of changes related to enthusiastic social behaviour of Chinese firms. As highlighted in Crifo and Forget (2015) socially responsible actions by local firms may be reciprocated over time by support from local stakeholders (customers, suppliers, employees, and so forth). Firms most likely to experience such reciprocity are firms with a stronger dependency on, and financial engagement with, local community actors. Local linkages are indeed very strong in Vietnam; 43 per cent of small firms in Vietnam sell their output in the same province, while 60 per cent of firms purchase raw materials, and 63 per cent of firms purchase intermediates from suppliers within the same province (CIEM et al., 2015). A strong community-related CSR effect is therefore not surprising in this context where firms are deeply rooted in the local community.

We explore this further in columns 5 and 6 of Table 3 by examining whether private domestic firms (sourcing most inputs locally and having the majority of their customers within the province/district of their main production facility) gain more from CSR initiatives than firms with a more outwardoriented business profile (enterprises with state and/or foreign ownership involvement). ${ }^{10}$ Results suggest that the positive relationship between CSR and firm efficiency is significantly stronger for domestic private firms as compared to state and foreign-operated firms, confirming that socially responsible actions by private domestic firms are likely to be reciprocated. ${ }^{11}$

As discussed in Section 4, there are several identification challenges in inferring a causal relationship from the estimates in Table 3. To address these, we use both static and dynamic system GMM estimators. The results are presented in Table 4 where all relevant instrument tests are carefully documented. All specifications pass the standard tests. Main results related to Equation (5) are presented in columns 1, 3 and 5 and results for the dynamic specification related to Equation (6) are presented in columns 2, 4 and 6. Results for the different sub-measures of CSR are documented in Appendix Table B in the Supplementary Materials. In all estimations, CSR is treated as endogenous, although treating CSR as predetermined (independent of current disturbances, but influenced by the past - through the lagged dependent variable), does not change the overall results reported. In columns 1 and 2, no CSR-HHI interaction or additional controls are included, whereas in columns 3 and 4 we add the CSR-HHI interaction, and in columns 5 and 6 supplement each specification with additional controls. The positive and well-determined effect of CSR on labour productivity found in Table 3 remains robust (only not well-determined in column 5), with slightly higher point estimates in the dynamic system GMM specifications. In addition, results in Table 4 suggest that CSR's differential impact on labour productivity along the sector concentration dimension generally remains positive and significant (only not well-determined in column 6).

Results from the static system GMM specification by CSR type (management and community) presented in Appendix Table B in the Supplementary Materials are consistent with the findings in Table 3. Community-level CSR continues to be the only CSR activity positively associated with firmlevel productivity. For each additional community-level, CSR initiative implemented firms see an improvement in labour productivity of 0.35 to 0.81 per cent, and this effect remains dependent on sector level concentration. Overall, we conclude that beyond-compliance management-related CSR initiatives (such as whether the firm has a written down CSR policy, is a member of standards groups, has agreements to promote CSR, or has been awarded CSR-type certifications) does not have an independent effect on firm-level productivity. However, for community-related CSR initiatives (such as firm-level involvement in local environmental protection activities, active participation in local poverty alleviation, education, and/or health programmes), there is an independent positive and welldetermined effect on firm-level productivity.

One possible mechanism through which community-level CSR initiatives impacts on firm performance is through worker incentives (see hypothesis 3 in Section 2). ${ }^{12}$ Akerlof and Kranton (2005) argue that CSR can be used strategically to signal a corporate culture that can help incentivise workers. Moreover, according to Crifo and Forget (2015), a strong CSR company profile may also motivate employees in a way that weakens workers' relative bargaining power in wage negotiations, 
Table 4. CSR, productivity and sectoral competitiveness - static and dynamic GMM estimates

\begin{tabular}{|c|c|c|c|c|c|c|}
\hline & 1 & 2 & 3 & 4 & 5 & 6 \\
\hline & $\begin{array}{c}\text { Static } \\
\text { Sys-GMM }\end{array}$ & $\begin{array}{l}\text { Dynamic } \\
\text { Sys-GMM }\end{array}$ & $\begin{array}{c}\text { Static } \\
\text { Sys-GMM }\end{array}$ & $\begin{array}{l}\text { Dynamic } \\
\text { Sys-GMM }\end{array}$ & $\begin{array}{c}\text { Static } \\
\text { Sys-GMM }\end{array}$ & $\begin{array}{l}\text { Dynamic } \\
\text { Sys-GMM }\end{array}$ \\
\hline \multicolumn{7}{|l|}{ Focus variables } \\
\hline CSR index $(0-12)$ & $\begin{array}{c}0.0034 * * \\
(0.0016)\end{array}$ & $\begin{array}{c}0.0046 * * \\
(0.0019)\end{array}$ & $\begin{array}{c}0.0025 \\
(0.0016)\end{array}$ & $\begin{array}{c}0.0041 \text { ** } \\
(0.0018)\end{array}$ & $\begin{array}{c}0.0019 \\
(0.0016)\end{array}$ & $\begin{array}{c}0.0038 * * \\
(0.0018)\end{array}$ \\
\hline Hirschman/Herfindahl Index (HHI) & $\begin{array}{c}-0.0375 * * * \\
(0.0135)\end{array}$ & $\begin{array}{c}-0.0378 * * * \\
(0.0140)\end{array}$ & $\begin{array}{c}-0.1143 * * * \\
(0.0308)\end{array}$ & $\begin{array}{c}-0.0871 * * * \\
(0.0317)\end{array}$ & $\begin{array}{c}-0.1029 * * * \\
(0.0304)\end{array}$ & $\begin{array}{c}-0.0709 * * \\
(0.0316)\end{array}$ \\
\hline CSR $* \mathrm{HHI}$ interaction & & & $\begin{array}{c}0.0348 * * * \\
(0.0121)\end{array}$ & $\begin{array}{l}\text { 0.0211* } \\
(0.0124)\end{array}$ & $\begin{array}{c}0.0305 * * \\
(0.0121)\end{array}$ & $\begin{array}{c}0.0162 \\
(0.0124)\end{array}$ \\
\hline \multicolumn{7}{|l|}{ Lagged dependent } \\
\hline Lagged employment per employee & & $\begin{array}{c}0.0707 * * * \\
(0.0108)\end{array}$ & & $\begin{array}{c}0.0712 * * * \\
(0.0108)\end{array}$ & & $\begin{array}{c}0.0752 * * * \\
(0.0105)\end{array}$ \\
\hline Efficiency controls & Yes & Yes & Yes & Yes & Yes & Yes \\
\hline Additional controls & No & No & No & No & Yes & Yes \\
\hline Obs. & 20,740 & 15,555 & 20,740 & 15,555 & 20,740 & 15,555 \\
\hline Firms & 5185 & 5185 & 5185 & 5185 & 5185 & 5185 \\
\hline No of Instruments & 20 & 22 & 26 & 28 & 32 & 34 \\
\hline $\mathrm{AB}$ test for $\mathrm{AR}(2)$ in first diff & 0.493 &.. & 0.538 &.. & 0.517 &.. \\
\hline Hansen OID test (p-value) & 0.745 & 0.312 & 0.129 & 0.685 & 0.554 & 0.708 \\
\hline Levels exclusion (p-value) & 0.933 & 0.589 & 0.705 & 0.791 & 0.788 & 0.835 \\
\hline Levels exogenous (p-value) & 0.284 & 0.153 & 0.283 & 0.396 & 0.218 & 0.381 \\
\hline CSR exclusion ( $\mathrm{p}$-value) &.. & 0.071 & 0.376 & 0.589 & 0.453 & 0.705 \\
\hline CSR exogenous (p-value) & .. & 0.682 & 0.625 & 0.618 & 0.551 & 0.526 \\
\hline Interaction exclusion (p-value) & .. &.. & 0.866 & 0.301 & 0.882 & 0.325 \\
\hline Interaction exogenous (p-value) & .. &.. & 0.246 & 0.941 & 0.238 & 0.941 \\
\hline Lagged dependent exclusion (p-value) & .. & 0.585 &.. & 0.888 &.. & 0.881 \\
\hline Lagged dependent exogenous (p-value) &.. & 0.154 &.. & 0.193 &.. & 0.226 \\
\hline IV exclusion ( $p$-value) & 0.662 & 0.209 & 0.557 & 0.593 & 0.330 & 0.527 \\
\hline IV exogenous ( $p$-value) & 0.600 & 0.548 & 0.391 & 0.644 & 0.658 & 0.704 \\
\hline
\end{tabular}

Source: Authors' calculations based on CIEM et al. (2015).

Notes: Dependent variable: Real revenue per employee (log). System GMM estimators. Twostep with the Windmeijer finite-sample correction for the two-step covariance matrix. t-statistics are reported in parentheses. $*, * *, * * *$ indicate significance at a 10 per cent, 5 per cent, and 1 per cent level, respectively. Using the CSR level relative to firm-level peers (defined by proximity and sector) do not, generally, change the results reported. Only in column 1 (static SYS-GMM with no interaction and no additional control variables included), relative CSR is not well-determined. The following 'additional controls' in columns 5 and 6 are well-determined: (i) ownership type $(+)$, (ii) exporter $(+)$, (iii) produce mainly for the final goods market $(+)$ and (iv) comply with regulations $(+)$.

thereby leading to an equilibrium outcome where workers are willing to accept lower wages in exchange for having a job in a well-respected company. To test this, we look at whether workers in comparable firms accept lower wage compensation (for a given productivity level) in enterprises with a stronger corporate social profile.

Appendix Figure 2 in the Supplementary Materials shows throughout the firm size distribution, that firms actively engaging in CSR activities tend to compensate their employees at a lower rate of total generated value added than their counterparts, which are less involved in CSR activities. We study more closely the relationship between CSR and labour compensation shares in Table 5 (and in Appendix Table $\mathrm{C}$ in the Supplementary Materials for CSR heterogeneity), both without (columns 1, 3 and 5) and with (columns 2, 4 and 6) controls for differences in firm-level productivity. As within-firm variation in labour compensation shares over the short time period considered is relatively modest, we address in Table 5 possible endogeneity bias in OLS estimates (in columns 1 and 2) using a static system GMM approach (columns 3 and 4) and an IV approach (columns 5 and 6) inspired by Cheng et al. (2014). The instruments for the latter include an average CSR Index (excluding the contribution of the firm itself) for each province-industry pair, and a time-varying component provincial competitiveness index (PCI) collected by the Vietnam Chamber of Commerce and Industry (see Malesky, McCulloch, \& Nhat, 
Table 5. Wage share and CSR

\begin{tabular}{|c|c|c|c|c|c|c|}
\hline & \multirow[b]{2}{*}{ OLS } & \multirow{2}{*}{$\frac{2}{\mathrm{OLS}}$} & \multirow{2}{*}{$\begin{array}{c}3 \\
\begin{array}{c}\text { Static Sys- } \\
\text { GMM }\end{array}\end{array}$} & \multirow{2}{*}{ 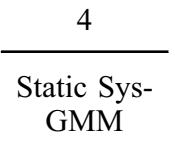 } & \multirow{2}{*}{$\frac{5}{\mathrm{IV}}$} & \multirow{2}{*}{$\begin{array}{c}6 \\
\text { IV }\end{array}$} \\
\hline & & & & & & \\
\hline \multicolumn{7}{|l|}{ Focus variables } \\
\hline CSR index $(0-12)$ & $\begin{array}{l}-0.0045 * * * \\
(0.0014)\end{array}$ & $\begin{array}{l}-0.0033 * * * \\
(0.0012)\end{array}$ & $\begin{array}{l}-0.0037 \\
(0.0023)\end{array}$ & $\begin{array}{l}-0.0048 * * \\
(0.0021)\end{array}$ & $\begin{array}{l}-0.0026 \\
(0.0051)\end{array}$ & $\begin{array}{c}-0.0081 * \\
(0.0045)\end{array}$ \\
\hline $\begin{array}{l}\text { Hirschman/Herfindahl Index } \\
\text { (HHI) }\end{array}$ & -0.0339 & $-0.0883 * * *$ & -0.0607 & $-0.1172 * * *$ & -0.0334 & $-0.0907 * * *$ \\
\hline & $(0.0221)$ & $(0.0197)$ & $(0.0444)$ & $(0.0399)$ & $(0.0223)$ & $(0.0198)$ \\
\hline CSR*HHI interaction & $\begin{array}{l}-0.0006 \\
(0.0073)\end{array}$ & $\begin{array}{c}0.0028 \\
(0.0060)\end{array}$ & $\begin{array}{c}0.0131 \\
(0.0175)\end{array}$ & $\begin{array}{l}0.0183 \\
(0.0155)\end{array}$ & $\begin{array}{l}-0.0038 \\
(0.0077)\end{array}$ & $\begin{array}{c}0.0054 \\
(0.0062)\end{array}$ \\
\hline Efficiency controls & No & Yes & No & Yes & No & Yes \\
\hline Additional controls & Yes & Yes & Yes & Yes & Yes & Yes \\
\hline Obs. & 18,466 & 18,466 & 18,466 & 18,466 & 18,454 & 18,454 \\
\hline Firms & 4,983 & 4,983 & 4,983 & 4,983 & 4,983 & 4,983 \\
\hline R-sq & 0.082 & 0.247 &.. &.. & 0.080 & 0.246 \\
\hline $\begin{array}{l}\text { Kleibergen-Paap (LM statistic - } \\
\text { p-value) }\end{array}$ &.. &.. & .. & .. & 0.000 & 0.000 \\
\hline KP Weak ID test (F-stat) & .. & .. & .. & .. & 341.09 & 341.60 \\
\hline Hansen OID test ( $p$-value) & .. & .. & .. & .. & 0.001 & 0.135 \\
\hline No of Instruments & .. & .. & 30 & 33 & .. & .. \\
\hline$A B$ test for $A R(2)$ in first diff & .. & .. & 0.152 & 0.137 & .. & .. \\
\hline Hansen OID test (p-value) & .. & .. & 0.362 & 0.337 &.. & .. \\
\hline Levels exclusion (p-value) & .. & .. & 0.273 & 0.195 & .. & .. \\
\hline Levels exogenous (p-value) & .. & .. & 0.520 & 0.644 & .. & .. \\
\hline CSR exclusion ( $\mathrm{p}$-value) &.. &.. & 0.133 & 0.234 &.. & .. \\
\hline CSR exogenous (p-value) & .. & .. & 0.716 & 0.482 & .. & .. \\
\hline Interaction exclusion (p-value) & .. & .. & 0.874 & 0.666 & .. & .. \\
\hline Interaction exogenous ( $p$-value) & .. &.. & 0.114 & 0.170 & .. & .. \\
\hline IV exclusion ( $\mathrm{p}$-value) &.. &.. & 0.245 & 0.547 & ... & ... \\
\hline IV exogenous (p-value) & .. & .. & 0.729 & 0.246 & .. & .. \\
\hline
\end{tabular}

Source: Authors' calculations based on CIEM et al. (2015).

Notes: Dependent variable: Wage share (total labour compensation as a share of value added). OLS, GMM and IV estimates. All specifications include time dummies in addition to the documented control variables. Columns 3 and 4: Static SYS-GMM estimator. Twostep with Windmeijer's finite-sample correction for the two-step covariance matrix. Columns 5 and 6: Jackknife instrumental variables estimation (JIVE) approach. Instruments: (i) Province-time average institutional quality and (ii) province-sector average CSR (leave-one-out). Standard errors (reported in parenthesis) are heteroskedasticity (cluster) robust. *, **, *** indicate significance at a 10 per cent, 5 per cent and 1 per cent level, respectively. Only one of the 'additional controls' are welldetermined throughout: Ownership type (-).

2015 for further details about the PCI data). ${ }^{13}$ As described in Cheng et al. (2014), the rationale behind these two instruments is that firm-level CSR provision is influenced by a time-invariant component that is associated with province-industry-level characteristics and a time-varying institutional component at the province level. The underlying assumption is therefore that the two components have a direct effect on firm-level CSR provision but no direct effect on labour compensation shares, conditional on firmlevel productivity, ownership form, production structure, and export and compliance status.

The results presented in Table 5 reveal that the relationship between CSR and the wage share is highly dependent on whether controls for differences in firm-level productivity are included in the empirical specification or not. This is not surprising as provision of CSR is found to be productivity enhancing and failure to control for this will tend to bias estimates towards zero. Moreover, although all test statistics for the static system GMM do not raise any specification concerns, the Hansen OID test statistic for the IV specification when not controlling for firm productivity (column 5) questions whether instruments are in fact exogenous. However, controlling for differences in firm-level efficiency in column 6, the model 
passes all relevance and weak identification tests. We therefore conclude that there is evidence of a negative and well-determined relationship between firm-level CSR provision and labour compensation shares. Moreover, results for different types of CSR presented in Appendix Table $\mathrm{C}$ in the Supplementary Materials consistently show that community-level CSR provision is the main driver. In sum, our results lend support to the confirmation of hypothesis 3 arguing that employees are willing to accept a lower share of value added in exchange for working in a company signalling 'good' corporate values, especially in cases where firms engage in more localised CSR initiatives.

\section{Conclusions}

This study used firm-level panel data covering more than 5,000 firms from Vietnam during the period 2011-2014 to examine the relationship between distinct types of CSR and firm-level performance. We asked three questions:

(a) Are CSR adopting firms more productive?

(b) Does CSR matter in competitive industries?

(c) Do firms use CSR strategically to offer lower labour compensation shares?

We found a positive relationship between CSR engagement and firm efficiency, and conclude that this positive effect is largely driven by CSR initiatives labelled as community-level CSR, that is, corporate socially responsible acts focused on servicing the local community (environmental protection activities, participation in local poverty alleviation programmes, community-based education, and/or health programmes). Firms that are more reliant on the local economy (for example, firms sourcing inputs at the district level and having most customers within the local community) are more likely to engage in socially responsible actions at the local community-level. Our results also indicate that corporate social initiatives are likely to be reciprocated through a workforce mechanism whereby employees are willing to accept a lower share of generated value added. Moreover, CSR impacts are found to be stronger for firms in non-competitive industries. Therefore, the hypothesis that competition mitigates managerial agency problems cannot be rejected, at least in the case of Vietnamese manufacturing firms.

Overall, our findings offer evidence that CSR may have an independent positive impact on firm-level efficiency in Vietnam; and that this positive productivity effect is driven more by the engagement of (smaller) domestic firms in local community CSR initiatives than more strategic CSR initiatives by larger corporations (state and/or foreign owned). Noting that foreign-owned enterprises are found to engage relatively less in community-based CSR initiatives than both state-owned enterprises and domesticowned firms (Newman, Rand, Tarp, \& Trifkovic, 2018) leads us to question the frequently found argument that increased foreign involvement in the economy will automatically bring about positive improvements in the corporate social behaviour of domestic firms through learning and spill-overs from foreign companies.

\section{Acknowledgements}

We are grateful for productive and stimulating collaboration with the analytical teams from CIEM and the GSO, Hanoi, Vietnam. The usual caveats apply.

\section{Disclosure statement}

No potential conflict of interest was reported by the authors. 


\section{Notes}

1. We acknowledge that these two components of CSR (CSR into strategy, and local community sponsorship) do not cover all dimensions of CSR. Our data does not allow us to include other potentially important dimensions of beyondcompliance CSR such as (a) innovative workplace practices towards employees, (b) responsible behaviours with customers and suppliers and (c) other dimensions of corporate governance. As such, our definition of CSR practices may not be fully aligned with other measures, which should be kept in mind when interpreting the results.

2. The Bénabou and Tirole (2010) model predicts a positive correlation between CSR and firm-level performance, but contrary to Porter and van der Linde (1995), Shleifer (2004), and Campbell (2007), the effect will be continuously diminishing in the level of industry competition.

3. In a few cases, firm information was inconsistent when merging the two different data sources. To ensure that we are merging identical firms across the two databases and over time, we checked that no major changes took place within the organisation of firms with respect to changes in location (province and district), changes in sector (at the 2 and 4-digit ISIC levels), and changes in legal structure.

4. We also considered measures computed at the 4-digit ISIC level when constructing the nationwide concentration index. This did not change our overall conclusion.

5. Short of strong theoretical guidance on how to weigh different components of the CSR index, we conduct a robustness check, relying on principal component analysis. Using the first principal component instead of the CSR index does not change the main results of the paper. In the reminder of the paper all CSR sub-components carry equal weight.

6. It should also be noted that the strict exogeneity assumption does not hold in models including a lagged dependent variable (Equation 6).

7. Results reported do not change using the nationwide HHI2.

8. The recalculated labour-coefficients based on $\beta_{n}=\beta_{N}+\beta_{K}+\beta_{M}-1$ are approximately 0.15 leading to RTS estimates around 0.99 .

9. Note that using the same data, Newman et al. (2018) find no systematic relationship between CSR adoption and industry competitiveness (defined at both the 2-digit or 4-digit ISIC level).

10. CIEM et al. (2015) documents that smaller private firms are more likely to source inputs locally and sell output to local customers than larger state and foreign-owned companies are.

11. Note also that for private domestic firms, we again find a positive and well-determined interaction effect, suggesting that CSR initiatives have larger effects on firm-level performance in non-competitive settings.

12. Another mechanism that could lead to this positive effect of community CSR on productivity is through exports (through learning-by-exporting) (Newman et al., 2018). However, coefficient estimates on community-level CSR are not affected by the inclusion of controls for export status (or ownership type).

13. The PCI data focuses on aspects of local governance which are under the control of the provincial administration. Accordingly, factors such as the quality or availability of national roads, airports and ports are not included (Malesky et al., 2015). We are therefore less concerned about biases in the index that favour larger cities or provinces, where we expect the culture around CSR provision to be more developed.

\section{References}

Akerlof, G. A., \& Kranton, R. E. (2005). Identity and the economics of organizations. Journal of Economic Perspectives, 19, 9-32.

Arellano, M., \& Bover, O. (1995). Another look at the instrumental variable estimation of error-components models. Journal of Econometrics, 68, 29-51.

Bagnoli, M., \& Watts, S. G. (2003). Selling to social responsible consumers: Competition and the private provision of public goods. Journal of Economics and Management Strategy, 12(3), 419-445.

Barrett, H. R., Browne, A. W., Harris, P. J. C., \& Cadoret, K. (2002). Organic certification and the UK market: Organic imports from developing countries. Food Policy, 27(4), 301-318.

Bénabou, R., \& Tirole, J. (2010). Individual and corporate social responsibility. Economica, 77(305), 1-19.

Besley, T., \& Ghatak, M. (2005). Competition and incentives with motivated agents. American Economic Review, 95(3), 616-636.

Blundell, R., \& Bond, S. (1998). Initial conditions and moment restrictions in dynamic panel data models. Journal of Econometrics, 87, 115-143.

Brekke, K. A., \& Nyborg, K. (2008). Attracting responsible employees: Green production as labor market screening. Resource and Energy Economics, 30(4), 509-526.

Brekke, K. A., \& Nyborg, K. (2010). Selfish bakers, caring nurses? A model of work motivation. Journal of Economic Behavior \& Organization, 75(3), 377-394.

Campbell, J. L. (2007). Why would corporations behave in socially responsible ways? An institutional theory of corporate social responsibility. The Academy of Management Review, 32(3), 946-967.

Carroll, A. B. (1979). A three-dimensional conceptual model of corporate performance. The Academy of Management Review, 4(4), 497-505. 
Central Institute for Economic Management (CIEM), GSO, \& University of Copenhagen. (2015). Firm-level technology and competitiveness in Vietnam evidence from 2010-2014 surveys. Hanoi: CIEM.

Chatterji, A., Levine, D., \& Toffel, M. (2009). How well do social ratings actually measure corporate social responsibility? Journal of Economics \& Management Strategy, 18(1), 125-169.

Cheng, B., Ioannou, I., \& Serafeim, G. (2014). Corporate social responsibility and access to finance. Strategic Management Journal, 35(1), 1-23.

Crifo, P., \& Forget, V. D. (2015). The economics of corporate social responsibility: A firm-level perspective survey. Journal of Economic Surveys, 29(1), 112-130.

Delmas, M. A., \& Pekovic, S. (2013). Environmental standards and labor productivity: Understanding the mechanisms that sustain sustainability. Journal of Organizational Behavior, 34(2), 230-252.

Giroud, X., \& Mueller, H. M. (2010). Does corporate governance matter in competitive industries? Journal of Financial Economics, 95, 312-331.

Gjølberg, M. (2009). Measuring the immeasurable?: Constructing an index of CSR practices and CSR performance in 20 countries. Scandinavian Journal of Management, 25(1), 10-22.

Heal, G. (2005). Corporate social responsibility: An economic and financial framework. The Geneva Papers on Risk and Insurance - Issues and Practice, 30(3), 387-409.

Hillman, A. J., \& Keim, G. D. (2001). Shareholder value, stakeholder management, and social issues: What's the bottom line? Strategic Management Journal, 22(2), 125-139.

Jensen, M. C. (2002). Value maximization, stakeholder theory, and the corporate objective function. Business Ethics Quarterly, $12(2), 235-256$.

Kitzmueller, M., \& Shimshack, J. (2012). Economic perspectives on corporate social responsibilities. Journal of Economic Literature, 50(1), 51-84.

Liu, Y. (2009). Investigating external environmental pressure on firms and their behaviour in Yangtze River Delta of China. Journal of Cleaner Production, 17(16), 1480-1486.

Malesky, E., McCulloch, N., \& Nhat, N. D. (2015). The impact of governance and transparency on firm investment in Vietnam. Economics of Transition, 23(4), 677-715.

Margolis, J. D., Elfenbein, H. A., \& Walsh, J. P. (2009). Does it pay to be good ... and does it matter? A meta-analysis of the relationship between corporate social and financial performance (SSRN Scholarly Paper No. ID 1866371). Rochester, NY: Social Science Research Network.

McWilliams, A., \& Siegel, D. (2001). Corporate social responsibility: A theory of the firm perspective. Academy of Management Review, 26(1), 117-127.

Newman, C., Rand, J., Talbot, T., \& Tarp, F. (2015). Technology transfers, foreign investment and productivity spillovers. European Economic Review, 76, 168-187.

Newman, C., Rand, J., \& Tarp, F. (2013). Industry switching in developing countries. The World Bank Economic Review, 27 (2), 357-388.

Newman, C., Rand, J., Tarp, F., \& Trifkovic, N. (2018). The transmission of socially responsible behaviour through international trade. European Economic Review, 101, 250-267.

Nguyen, Q. V. (2007). Current status of CSR in Viet Nam (Vietnam Chamber of Commerce and Industry (VCCI) Working Paper). Hanoi: Business Office for Sustainable Development.

Nyborg, K. (2014). Do responsible employers attract responsible employees? IZA World of Labor.

Nyborg, K., and T. Zhang (2013). Is corporate social responsibility associated with lower wages? Environmental and Resource Economics, 55(1), 107-117.

Ockenfels, A., \& Weimann, J. (1999). Types and patterns: An experimental East-West-German comparison of cooperation and solidarity. Journal of Public Economics, 71(2), 275-287.

Porter, M. E., \& Kramer, M. R. (2002). The competitive advantage of corporate philanthropy. Harvard Business Review, 80 (12), 56-68.

Porter, M. E., \& van der Linde, C. (1995). Toward a new conception of the environment-competitiveness relationship. The Journal of Economic Perspectives, 9(4), 97-118.

Schwartz, M. S., \& Carroll, A. B. (2003). Corporate social responsibility: A three-domain approach. Business Ethics Quarterly, $13(4), 503-530$.

Shleifer, A. (2004). Does competition destroy ethical behaviour? American Economic Review, 94(2), 414-418.

Thomson Reuters. (2014). Thomson Reuters Corporate responsibility indices. Retrieved from https://financial.thomsonreuters. com/content/fr/en/products/data-analytics/company-data/esg-research-data.html

Trifkovic, N., Markussen, T., Newman, C., \& Rand, J. (2018). Chapter 21: Corporate social responsibility in Vietnam. In S. Hsu (Ed.), Routledge handbook of sustainable development in Asia (pp. 427-448). Abingdon: Routledge.

Turker, D. (2009). Measuring corporate social responsibility: A scale development study. Journal of Business Ethics, 85(4), 411-427.

UN. (2004). The Global Compact leaders summit 2004 - final report. UN Global Compact. Retrieved from https://www. unglobalcompact.org/library/255

UN. (2013). The ten principles of the UN Global Compact. Retrieved from https://www.unglobalcompact.org/what-is-gc /mission/principles. 
UN. (2014). The Global Compact Viet Nam network'. Retrieved from http://www.un.org.vn/en/spotlight-articles-press-centresubmenu-253/news-highlights-press-centre-submenu-254/27-the-un-in-viet-nam/global-compact/295-the-global-compactviet-nam-network.html

Waddock, S. A., \& Graves, S. B. (1997). The corporate social performance-financial performance link. Strategic Management Journal, 18(4), 303-319.

Waldman, D. A., Siegel, D. S., \& Javidan, M. (2006). Components of CEO transformational leadership and corporate social responsibility. Journal of Management Studies, 43(8), 1703-1725. 